\title{
Die Hervormde Teologiese Studies na vyftig jaar
}

\author{
Prof dr A D Pont \\ Emeritus-professor, Universiteit van Pretoria
}

\section{INLEIDEND}

In die tweede helfte van die jaar 1943 het die Hervormde Teologiese Studies die eerste maal verskyn. Dit was die produk van lang besinning en beplanning. Die dryfkrag agter die totstandkoming was prof dr S P Engelbrecht, 'n man wie se idealisme en toewyding aan die kerk groot dinge vir die kerk en ook die Afrikanervolk tot stand gebring het. Hoewel die jaar 1943 midde in die wêreldoorlog geval het, daar allerlei beperkings en rantsoenerings vanweë die oorlog was, finansiële middele in die kerk en aan die universiteit beperk was, het die blad tog verskyn en die titel gedra: Hervormde Teologiese Studies vir die bevordering van die Bybels. Reformatoriese teologie in Suid-Afrika. In die Woord vooraf word 'n verantwoording van die titel gegee en onder andere gestel:

Die doel wat beoog word is ... allereers die bevordering van die studie van die Bybel. Die Heilige Skrif tog is die bron en die norm van ons Godskennis ... Ons wil terug na die bron, ons wil die lewende water van die direkte onafgeleide Godsopenbaring ....

Ten tweede wil ons kinders van die Hervorming wees ... Ons wil kinders wees van die Geestesbeweging wat sig van hulle (dit is: die groot Hervormers) as draers en instrumente bedien het.

Ten derde wil ons die teologie dien op die plek en in die kring waarin ons ons deur God geroepe en gestel ag, in die Kerk waarin na ons oortuiging die stroom van die Bybelse waarheid ... kragtig en suiwer voortstroom: die Hervormde Kerk.

Van die begin af was die tydskrif nie bedoel as 'n eksklusiewe vaktydskrif wat net moes voldoen aan die 'begeerte ... na 'n eie plek om die resultate van wetenskaplike godgeleerde ondersoek van ons professore en predikante te publiseer' nie. Daarom stel die eerste redaksie:

Die kring van ons lesers stel ons ons so ruim moontlik voor. Van vertoon van geleerdheid wil ons ons onthou. Egte wetenskap moet in eenvoudige woorde vir ieder verstandige mens verstaanbaar uitgedruk kan word. 
Dit was dus met groot voornemens dat die eerste uitgawe van die Studies die lig gesien het. Iets van die verwagtings ten opsigte van die blad is verwoord deur ds T F J Dreyer, die destydse skriba van die Kommissie van die Algemene Kerkvergadering. In sy Welkomswoord het hy 'n pleidooi gelewer vir 'n Suid-Afrikaanse teologie en dit so gestel:

Ja seker, 'n Suid-Afrikaanse teologie bestaan nog nie. Ons het nog maar steeds ... die Westerse teologie geleer, gepropageer en bely en meer bepaald die Nederlandse teologie ....

En soos ons 'n eie taal en geskiedenis het ... so moet ons ook ons eie teologie hê en so verlang ons ook dat ons teologie tot 'n sekere mate 'n eie Suid-Afrikaanse karakter moet vertoon ... Ons wil nie van die ou tradisie ons losmaak nie ... ons wil die ou tradisie handhaaf, ons wil op die ou fondament voortbou. Dit is die fondament wat met die kerkhervorming gele is ... Die suiwer reformatoriese beginsels wil ons handhaaf, verdedig, aksentueer.

So het die Studies sy verskyning gemaak en drie van die destydse professore het vir die eerste uitgawe ' $n$ bydrae gelewer: J H J A Greyvenstein, B Gemser en S P Engelbrecht. Hulle bydraes is aangevul met 'n bydrae van ds Joh Dreyer. Die eerste jaargang wat 196 bladsye in omvang was, is grotendeels gedra deur bydraes van prof Gemser met 6 artikels, prof $S$ P Engelbrecht met 5 artikels en prof Greyvenstein met 2 artikels. Dan was daar ook bydraes van ds $W$ van Bergen, ds Joh Dreyer, ds (later prof dr).E S Mulder en ds (later prof dr) F J van Zyl. Dan was daar bydraes van die klassikus dr Hilgard Muller wat later as politikus ' $n$ rol in landsake gespeel het, die bekende historikus dr J Ploeger en ds (later prof dr) P F D Weiss van die Nederduitse Gereformeerde Kerk wat destyds by prof Gemser gestudeer het. Dit is opvallend dat prof H P Wolmarans aanvanklik geen bydraes gelewer het nie. Hy het eers met die derde jaargang in 1946 'n eerste artikel beskikbaar stel. Dit kan dui op spanninge wat in die teologiese fakulteit bestaan het vanweè die oorlog en Suid-Afrika se deelname daaraan onder die leiding van die Eerste Minister en Engelse veldmaarskalk, J C Smuts.

\section{IETS OOR DIE RI:DAKSIE}

Die Studies was van die begin af ' $n$ tydskrif wat deur die teologiese fakulteit hanteer en beheer is en was, aanvanklik, die spieël wat die navorsing en denke in die teologiese fakulteit gereflekteer het. Dit het gou duidelik geword dat die teologiese fakulteit 'n positiewe bydrae wou lewer tot die teologiese debat in en om die kerk. 
Hoewel die oprigting van die blad heelwat beplanning geverg het, was die volhou van hierdie poging 'n saak wat hoë eise aan die lede van die teologiese fakulteit gestel het. Daarvan kan almal getuig wat op een of manier betrokke was by voortsetting van die Studies.

Die redaksiekomitee is aanvanklik aangedui as die lede van die teologiese fakulteit. Met die vierde jaargang (1947/1948) word gestel dat die redaksie bestaan uit professore S P Engelbrecht, B Gemser, A S Geyser, A van Selms en J de Zwaan. Laasgenoemde was op daardie stadium die Nuwe-Testamentikus aan die Universiteit van Leiden. Prof de Zwaan se teenwoordigheid op die redaksie het nie alleen die aansien van die nuwe blad ten goede gekom nie, maar het ook gedui op die skakel wat nog steeds met die Nederlandse teologiese en universitêre wêreld gehandhaaf is. Met sy uittrede uit die redaksie in 1951 word in sy plek prof $\mathrm{dr} \mathrm{H}$ W Obbink van die Universiteit van Utrecht benoem. Hy het vir tien jaar lid van die redaksie gebly.

Geleidelik is die redaksie uitgebrei om wyer te vat as net die lede van die Fakulteit Teologie (Afdeling A) van die Universiteit van Pretoria. So kom in 1948 die latere prof $\mathrm{E} S$ Mulder by. Op daardie stadium was dit vir 'n tyd lank die gebruik om saam met die lede van die Fakulteit ook die gedoktoreerde predikante van die Nederduitsch Hervormde Kerk op die redaksie te benoem. Die breë redaksie is tot 1961 op hierdie wyse saamgestel want in daardie jaar was, naas die lede van die teologiese fakulteit en prof P S Dreyer, professor in Wysbegeerte aan die Universiteit van Pretoria, die oud-lede van die teologiese fakulteit, met name prof $B$ Gemser (toe verbonde aan die Universiteit van Groningen), prof S P Engelbrecht en prof H P Wolmarans, saam met prof $H$ W Obbink van Utrecht, dr S P J J van Rensburg, dr J A A A Stoop en dr B J van der Merwe, almal lede van die redaksie.

Vanaf 1962 is die redaksie egter gewysig, en word dit weer verklein en bestaan dan net uit die lede van die teologiese fakulteit, bygestaan deur prof P S Dreyer. Prof Dreyer was verantwoordelik vir die boekbesprekings en het lid van die redaksie gebly tot en met die aanvaarding van sy emeritaat as professor en hoof van die Departement Wysbegeerte aan die Universiteit van Pretoria. Die wysiging het ook saamgehang met die feit dat die blad afhanklik was van fondse wat deur die Universiteit beskikbaar gestel is en dit moes in die samestelling van die redaksie gereflekteer word. Daarby het die samestelling van die redaksie in 1962 ook iets uitgedruk van die meningsverskille wat in die jare 1960-1964 in die teologiese fakulteit na vore gekom het.

Vandag bestaan die redaksie nog steeds uit die lede van die teologiese fakulteit met die dekaan, prof $\mathbf{J} \mathbf{H}$ Koekemoer, as voorsitter en dr P J de Beer, direkteur van die Tydskrifafdeling van die Nederduitsch Hervormde Kerk as redaksiesekretaris. Prof A G van Aarde is die redakteur en in sy taak word hy gerugsteun deur die Tydskrifafdeling. 


\section{DIE VERSORGING VAN DIE SIUDIES}

Die versorging en die bedryf van die Studies is vanselfsprekend 'n groot taak en dit is tog belangrik om hieraan 'n oomblik die aandag te gee, want dit waarborg die reëlmatige verskyning van die tydskrif.

Die eerste voorsitter van die redaksie was prof dr B Gemser, met prof dr S P Engelbrecht as die sekretaris van die redaksie wat terselfdertyd die versorging van die blad waargeneem het. Die blad, wat so baie te danke gehad het aan die dryfkrag van prof S P Engelbrecht, is in die eerste jare gedra en versorg deur sy onvermoeibare geesdrif. Vanaf die tiende jaargang (1953/1954) het prof B J Engelbrecht, wat in 1952 lid van die teologiese fakulteit geword het, opgetree as sekretaris van die redaksie. Prof Engelbrecht het die taak behartig tot en met Jaargang 38 (1982). Dan word die funksie van sekretaris van die redaksie deur prof A D Pont oorgeneem, terwyl professore A P B Breytenbach en A G van Aarde die publikasie-sekretariaat onder hulle sorg geneem het.

Die versorging van die blad, die insameling van artikels en die voorbereidingswerk vir publikasie is van 1957 af eers deur prof A D Pont waargeneem en daarna, vanaf 1971, deur prof J P Oberholzer. Vanweë die feit dat die insameling en keuring van artikels en die redaksionele versorging algaande 'n groter omvang gekry het, is daar hulp gesoek en gevind by die Raad van Finansies van die Nederduitsch Hervormde Kerk van Afrika.

In 1985, met Jaargang 41, is die taakverdeling op die redaksie weer gewysig in die sin dat prof A G van Aarde as redakteur aangewys is en dr D J C van Wyk, op daardie stadium direkteur vah die Tydskrifafdeling van die Nederduitsch Hervormde Kerk van Afrika, die sekretariaat oorneem en die administratiewe en tegniese versorging van blad grotendeels deur die redakteur en die Tydskrifafdeling behartig word.

Hierdie ontwikkeling het die Studies in 'n hoë mate bevoordeel en het die tydskrif in omvang laat groei. So het die tydskrif in 1991 ' $n$ omvang van 1151 bladsye gehad, in 1992 weer 1036 en in 1993 (Jaargang 49) 1048. Dit was 'n groot sprong. want die eerste jaargang het slegs 196 bladsye beloop. Die omvang van ongeveer 200 bladsye per jaargang is vir baie jare gehandhaaf maar vanaf Jaargang 40) het die omvang begin groei, ook vanweẹ toenemende belangstelling in die blad van buite die kring van die Nederduitsch Hervormde Kerk. As voorbeeld van die Studies se bekendheid in die buiteland, kan vermeld word dat die volgende buitelandse bibliografiese indekse opsommings van die artikels in die Studies in Engels publiseer: die Editrice Pontificio Instituto Biblico in Rome se Elenchus of Biblical Bibliography, die American Theological Library Association in Evanston, Illinois se Religion Indexes, die Zeller Verlag in Osnabrück, Duitsland se Intemarional Biblio- 
graphy of Periodical Literature (IBZ) and International Bibliography of Book Reviews of Scholarly Literature, die Université Laval in Quebec, Kanada se Bibliographical Information Bank in Patristics, die Catholic University of America in Washington, DC se Old Testament Abstracts, die Weston School of Theology in Cambridge, MA se New Testament Abstracts en die Religious and Theological Abstracts wat in Meyerstown, VSA uitgegee word. Hierbenewens is talle universiteitsbiblioteke oor die hele Europa, Noord-Amerika en Suid-Afrika op die Sludies ingeteken en bestaan daar ook uitruilooreenkomste met ander vaktydskrifte in Frankryk, Nederland, Kenia, Hong Kong en met 'n groot aantal in Suid-Afrika.

Die feit dat universiteite in Suid-Afrika sedert die tagtigerjare subsidie van die Departement van Nasionale Opvoeding op grond van die publikasie van universiteitspersoneellede se navorsingsuitsette in geakkrediteerde nasionale en internasionale vaktydskrifte ontvang, het sterk daartoe bygedra dat die Studies uitgebrei is. Die Studies is sedert die eerste akkreditering deur die Departement van Nasionale Opvoeding geplaas op die lys van nasionale en internasionale goedgekeurde wetenskaplike tydskrifte. Die implikasie hiervan was dat die inhoudelike en formele keuring van die navorsingsartikels deur die redakteur aan 'n streng keuringsproses begin onderwerp is. Akademici wat as gevolg van hulle wetenskaplike uitnemendheid akademiese statuur verwerf het en wat afkomstig is uit kringe buite die Nederduitsch Hervormde Kerk, is sedertdien by die evalueringsproses van bykans al die navorsingsartikels wat vir publikasie ingedien is, betrek. Hiermee is terselfdertyd 'n kontrole deur die redakteur ingebou om toe te sien dat eksterne evaluering sorgdra dat die bydraes uit die kring van die Nederduitsch Hervormde Kerk self aan hoë akademiese standaarde voldoen en dat die belange van die teologiese wetenskap in die algemeen naas dié van die eie kring gedien word. Hierdie akkrediteringsprosedure het nie net die Universiteit van Pretoria en die Fakulteit Teologie (Afdeling A) finansieel ten goede gekom nie, maar terselfdertyd die druk op die Teologiese Opleidingsfonds van die Nederduitsch Hervormde Kerk verlig. Die lede van die teologiese fakulteit het deur middel van die publikasie van hulle navorsingsuitsette byvoorbeeld in 1990 die bedrag van $R 444$ 815 verdien, in 1991 R 350001 en in 1992 R 435468 . Hierdie feit het regstreeks daartoe bygedra dat die navorsingsfonds van die Fakulteit Teologie (Afdeling $A$ ) die bedrag van R 81163 vir 1992 ontvang het, vir 1993 R 73673 en vir 1994 R 106 590. Dit was veral prof $A G$ van Aarde wat as redakteur die blad van ' $n$ uitsluitlike fakulteitsblad uitgebou het na 'n tydskrif waarin medewerkers van verskillende kerke, universiteite en lande wil publiseer. In Jaargang 47 (1991) is byvoorbeeld vier en vyftig navorsingsartikels gepubliseer waarvan nege en twintig uit eie kring en vyf en twintig van buite die Hervormde Kerk gekom het. So het die Studies 
geleidelik 'n tydskrif geword wat die teologiese debat en meningswisseling in 'n breë verband dien, sonder dat die lede van die teologiese fakulteit te kort gedoen word wat die publikasie van die eie navorsingsresultate betref. Tot op datum is daar ook vyf monografieë in die HTS Supplementum-Reeks gepubliseer. Hierdie addisionele supplementa dien as voorgeskrewe handboeke vir teologiese studente.

Dit is ook interessant om op die prys van die Studies te let. In 1943 is dit vasgestel op R2 per jaar. As die ontwaarding van die Suid-Afrikaanse geld in ag geneem word en die tabelle wat dit bereken, geraadpleeg word, beteken dit dat R2 in 1943 ongeveer die koopkrag gehad het van R95 vandag. In 1970 is die intekengeld verhoog na $\mathrm{R} 4$ en dit verteenwoordig in ons hedendaagse geld ongeveer $\mathbf{R} 80$. As in aanmerking geneem word dat die jaarlikse intekenprys in 1994 R65 (die ontvangs van die addisionele supplementa ingesluit) bedra het, dan beteken dit, in die reële koopkrag van die Rand bereken, dat die Studies algaande goedkoper geword het!

\section{SLOTOPMERKINGS}

Vandag, vyftig jaar nadat die eerste aflewering van die Hervormde Teologiese Studies verskyn het, kan daar met 'n hoë mate van tevredenheid teruggekyk word op hierdie taak wat die teologiese fakulteit in 1943 aangepak het. Hoewel met hierdie terugblik net gelet is op 'n paar formele aangeleenthede rondom die blad en sy bestaan, kan daar tog gesê word dat die teologiese fakulteit met die oprigting en instandhouding van die Studies 'n groot diens aan die kerk en aan die teologie in ons land gelewer het. 'n Taakwat nog aangepak sal moet word, is om die teologiese koers en bydrae wat die Studies inderdaad deur die jare aangedui en gelewer het, te peil en te orrskrywe. Eers as dit gedoen is, sal die waarde van die werk wat gedoen is, werklik gepeil kan word. Dit staan egter vas dat die teologiese fakulteit, in die breë gesien, die taakopdrag tot navorsing, publikasie en bevordering van die teologiese wetenskap met sorg en aandag uitgevoer het. Hoeveel van die mensewerk blywende waarde vir die kerk sal hê, sal die tyd ons seker nog moet leer.

Daar is egter groot dankbaarheid dat die taak om op hierdie wyse kerk en teologie te dien, só gegroei het. Wanneer nou na vyftig jaar 'n oomblik teruggekyk word, kan gesê word dat die Here God ook hierdie onderneming geseën het en telkens mense voorsien het wat die taak met erns en toewyding aangepak en uitgevoer het, om só kerk en koninkryk te dien tot eer van sy Naam. 